\title{
On Adaptation: An Apology
}

\section{To}

The Editor of Ophthalmologica

Basel

Sir:

Owing to war circumstances, I had to write my articles on adaptation (Ophthalmologica, 1945, $110,138)$ without having access to any library. I therefore had to refrain from giving authors' names or references to literature.

In some readers, this seems to have created the impression that I wanted to infringe on the priority rights of other authors who were not named by me, and whose ideas I used and tried to improve. This applies in particular to the idea of writing the adaption curve as an almost fluent line by means of immediate registration. The importance of this has already been stressed many years ago by professor G. F. Rochat of Groningen, who also built and published a self-recording adaptometer to this purpose (Ned. Tijdschr. Gen. 1941, I, 1125).

This instrument I knew quite well, and it never was my intention to give your readers the idea that I was the first and sole inventor of such an apparatus. I want to state expressly that I do not claim any priority or originality of the ideas described in the articles named above, and I

apologize to any author in this field whose name and work I should have mentioned,--and would have mentioned if circumstances had permitted me to do so.

I am, Sir, Yours sincerely, Dekking.

Richtigstellung.

H.Dr. Herr Dr. F. P. Fischer bittet im Hinblick auf die Angabe von v. Heuven auf Seite 98

Band 110

dieser Zeitschrift

er habe eine doppelte Repräsentation der Macula angenommen

darauf hin-zuweisen

daß er sich zu dieser Frage

die seinem Arbeitsgebiet ganz fernliegt

niemals geäußert habe. 